\title{
RADIOACTIVE GRAPHITE DISPERSION IN THE ENVIRONMENT IN THE VICINITY OF THE CHERNOBYL NUCLEAR POWER PLANT
}

\author{
Michael Buzinny \\ The Marzeyev Institute for Hygiene and Medical Ecology, Academy of Medical Sciences of Ukraine, 50 Popudrenko Str., \\ 02660 Kiev-94, Ukraine. Email: mbuz@ukr.net.
}

\begin{abstract}
This paper estimates the radioactive graphite dispersion on the land surface (forest litter and soil) as a result of the Chernobyl Nuclear Power Plant (NPP) release. Graphite mass was calculated using an estimated average concentration of $2.5 \times 10^{7} \mathrm{~Bq} / \mathrm{kg} \mathrm{C}$ (carbon). The sample collection method, sample origin and its mass, and sample preparation procedure used for preparation of benzene were taken into account to obtain the optimum sensitivity of the method. Thus, the sensitivity of the corresponding method for graphite detection in forest litter was estimated to be $0.2 \mathrm{mg} / \mathrm{m}^{2}$. All analyses gave a range of deposited graphite from 0.12 to $52.6 \mathrm{mg} / \mathrm{m}^{2}$. The maximum value was observed at a site located $9 \mathrm{~km}$ west of the Chernobyl NPP. The results of the study indicate the importance of studying the upper layer of soil $(0-5 \mathrm{~cm})$ in addition to the lower layer of forest litter.
\end{abstract}

\section{INTRODUCTION}

Reconstruction of the processes that occurred at the 4th reactor of the Chernobyl Nuclear Power Plant (NPP) in the initial period of the accident (26 April to 5 May 1986) could clarify some answers to a number of important questions about the accident. ${ }^{14} \mathrm{C}\left(\mathrm{T}_{1 / 2}=5730 \mathrm{yr}\right)$ is one of the long-lived radionuclides released during nuclear accidents. ${ }^{14} \mathrm{C}$ accumulated in the graphite stacks of the Chernobyl NPP during the operation of the reactor. Due to the accident, the reactor graphite partially burned and dispersed, forming the 2 main components of ${ }^{14} \mathrm{C}$ release: a gaseous component $\left(\mathrm{CO}_{2}\right)$ and an aerosol component (graphite dust). This combination formed a trace in the environment that remained for a long period of time. This is the ${ }^{14} \mathrm{C}$ accumulated from $\mathrm{CO}_{2}$ in annual tree rings and graphite dust deposited in the system "forest litter - soil." Most of the investigations of ${ }^{14} \mathrm{C}$ originating from the Chernobyl NPP were performed using tree-ring analysis. Results of the tree-ring analysis allowed us to estimate a total gaseous release and its daily variations during the accident (Buzinny et al. 1998). The ${ }^{14} \mathrm{C}$ variation analyzed for a wide time span (1978-1999) for 2 trees in the vicinity of Chernobyl NPP also allowed for estimating ${ }^{14} \mathrm{C}$ operational releases (Buzinny and Talerko 2000b).

Other types of environmental samples analyzed were plants and grasses collected in 1986. These samples show very high levels of ${ }^{14} \mathrm{C}$ at different observation sites (Buzinny et al. 1993). The ${ }^{14} \mathrm{C}$ activity of samples was formed by both gaseous (structural contamination) and aerosol (surface contamination of the samples) components, which cannot be separated.

Some aspects of ${ }^{14} \mathrm{C}$ behavior in the forest ecosystem around the Chernobyl NPP are described by Kovaliukh et al. (1998). We assume that the system "forest litter - soil" is stable enough to preserve graphite dust for the period since the accident up to the time of sampling, in the summer of 1997. As the stability and behavior of graphite are not the topic of this paper, this issue should be studied separately. Our study of graphite deposition in the environment was aimed at the determination of the peculiarities of the graphite distribution.

\section{Evaluation of ${ }^{14} \mathrm{C}$ Deposition in the Reactor Graphite}

Analysis of the dispersion of ${ }^{14} \mathrm{C}$ components deposited in the environment during the accidental release is complicated by 2 factors. The first factor is the uncertainty of ${ }^{14} \mathrm{C}$ activity deposited in the reactor graphite at the moment of the accident, and the second factor is the uncertainty of measurements of the gaseous and aerosol components from the releases. 
The stack of the 4th Chernobyl NPP reactor contained 1850 tons of graphite (Gaiko et al. 1985), and the activity of ${ }^{14} \mathrm{C}$ accumulated in graphite during the operation of the 4th reactor was estimated to be $100 \mathrm{TBq}$ (Begichev et. al. 1990). Direct measurements of 4 samples of graphite fragments from the 4th reactor of the Chernobyl NPP gave a maximum value of $2.5 \times 10^{7} \mathrm{~Bq} / \mathrm{kg}$, and the corresponding estimate of total activity in the graphite was $46 \mathrm{TBq}$ (Buzinny et al. 1993). The deposition intensity of ${ }^{14} \mathrm{C}$ for the RBMK-1000 reactor was estimated to be $3300 \mathrm{GBq} / \mathrm{TWt}(\mathrm{E})$ (Salonen 1987). Hence, the ${ }^{14} \mathrm{C}$ deposition equals $187 \mathrm{TBq}$ during the $570 \mathrm{~d}$ of the 4th reactor's operation (for the average reactor power of $10.9 \mathrm{MWt} / \mathrm{day}$ ). According to the estimates given by Borovoi (1995), a significant part of graphite burned during the active stage of the accident, and a lesser part was discharged as finely dispersed dust and deposited in the environment. About 700 tons of graphite $(\sim 38 \%)$ was estimated to have remained in the reactor. Using high estimates of total ${ }^{14} \mathrm{C}$ activity in graphite $(100$ and $187 \mathrm{~Bq})$, the remaining graphite in the reactor was estimated to have ${ }^{14} \mathrm{C}$ in the range of 38 and $68 \mathrm{TBq}$, respectively (Buzinny et al. 1998).

\section{Estimation of the Amount of ${ }^{14} \mathrm{C}$ Gaseous Discharges}

To determine the specifics of ${ }^{14} \mathrm{C}$ spatial dispersion in the accidental releases at the Chernobyl NPP, Buzinny et al. $(1993,1998)$ performed a study of ${ }^{14} \mathrm{C}$ deposited in annual tree rings (1985-1987). The results covered more than 60 sites where wood was collected and allowed us to determine both daily releases during the active stage of the accident and the spatial dispersion of the releases (Buzinny and Talerko 2000a). We determined that the total ${ }^{14} \mathrm{C}$ gaseous discharges were $\sim 50 \mathrm{TBq}$. The aerosol fraction deposited in the environment covered a wide range from 12 to $62 \mathrm{TBq}$ (Buzinny et al. 1998).

\section{METHODS}

To estimate the activity of the dispersed ${ }^{14} \mathrm{C}$ and the graphite, we used 2 components of ${ }^{14} \mathrm{C}$ : ${ }^{14} \mathrm{C}$ graphite activity and the activity of the ${ }^{14} \mathrm{C}$ natural component in plant material. To evaluate the 2 methods of sample preparation (a conventional one including prior pyrolysis of the organic matter and a second method of direct synthesis of lithium carbide [Skripkin and Kovaliukh 1998]), we performed a sample count rate comparison for both ${ }^{14} \mathrm{C}$ components in forest litter (graphite and natural carbon) in corresponding samples using Equations 1 and 2:

$$
\begin{gathered}
C P M_{\text {graphite }}\left(\text { count } \cdot \min ^{-1}\right)=M_{\text {litter }} \times A_{\text {graphite }} \times \frac{\sigma}{M_{s}} \times \frac{S}{S_{0}} \times E_{\text {graphite }} \times E_{L S C} \times 60 \\
C P M_{\text {litter }}\left(\text { count } \cdot \mathrm{min}^{-1}\right)=M_{\text {litter }} \times A_{\text {litter }} \times E_{\text {litter }} \times E_{L S C} \times 60
\end{gathered}
$$

where $A_{\text {graphite }}{ }^{1}=2.5 \times 10^{7} \mathrm{~Bq} / \mathrm{kg}$; only one of the 3-4 estimations mentioned above is in the range $(2.5-10.0) \times 10^{7} \mathrm{~Bq} / \mathrm{kg} ; M_{\text {litter }}=8 \mathrm{~g}$ or $40 \mathrm{~g}$ (mass of litter sample used by 2 different methods); the subscript $l_{\text {litter }}$ is the density of graphite deposition onto the land surface $\left(\mathrm{mg} / \mathrm{m}^{2}\right) ; M_{s}$ is the mass in grams the forest litter sample $\left(50 \times 50-\mathrm{cm}\right.$ sampling square); $S / S_{0}=0.25$ is the part of the area where forest litter was sampled; $E_{\text {graphite }}=0.8$ (the chemical yield of benzene synthesis in forest litter); $A_{\text {litter }}=0.5 \times 0.92 \times 0.226 \mathrm{~Bq} / \mathrm{g}, 0.5$ is the fraction of carbon in forest litter, 0.92 is the fraction of carbon in benzene, and $0.226 \mathrm{~Bq} / \mathrm{g}$ is the specific activity of ${ }^{14} \mathrm{C}$ "modern" carbon of objects in the environment); $E_{\text {litter }}=0.45$ and 0.12 (the chemical yield of benzene synthesis for the 2 applied methods); and $E_{L S C}$ is the efficiency of ${ }^{14} \mathrm{C}$ counting in benzene (80\%).

The expected count rate for samples undergoing both methods of preparation is given in Table 1. The table shows that the ratio signal/background (the natural level of ${ }^{14} \mathrm{C}$ is background) is the best one for the "conventional" method. This method is the most sensitive as it can be applied to samples

${ }^{1}$ Only one value is used to show the order of graphite deposition mass $\left(\mathrm{mg} / \mathrm{m}^{3}\right)$. 
with a density of graphite deposition of $n \times 10^{-4} \mathrm{~g} / \mathrm{m}^{2}$ compared to $n \times 10^{-3} \mathrm{~g} / \mathrm{m}^{2}$ used for the other method (Buzinny et al. 2000). Unfortunately, high uncertainty and low reproducibility (during pyrolysis some graphite dust could burn) in the chemical yield of benzene from graphite during sample preparation encouraged us to adopt the second method (see Skripkin and Kovaliukh 1998). Therefore, the sensitivity of this alternative method (Skripkin and Kovaliukh 1998) is sufficient for our sample analyses, even when considering the most pessimistic variant of density for graphite deposition.

Table 1 Expected count rate (CPM) for forest litter samples containing deposited graphite for different methods of samples preparation.

\begin{tabular}{lcll|lll}
\hline \multirow{2}{*}{\begin{tabular}{l}
$\mathrm{g} / \mathrm{m}^{2}$ \\
\cline { 2 - 7 }
\end{tabular}} & \multicolumn{3}{c|}{ Conventional method } & \multicolumn{3}{c}{ Alternate method (Skripkin and Kovaliukh 1998) } \\
\hline $10^{-2}$ & 240 & Forest litter & Ratio & Graphite & Forest litter & Ratio \\
$10^{-3}$ & 28.8 & 8.33 & 48 & 21.6 & 2.22 \\
$10^{-4}$ & 2.4 & 28.8 & 0.83 & 4.8 & 21.6 & 0.22 \\
\hline
\end{tabular}

The amount of ${ }^{14} \mathrm{C}$ deposited in each layer and for each collecting site was estimated by determining ${ }^{14} \mathrm{C}$ activity according to the equation:

$$
{ }^{14} \mathrm{Cs}=\mathrm{Cs} \times \mathrm{A}_{14 \mathrm{C}}
$$

where $C s$ is the mass $(\mathrm{kg})$ of carbon in the analyzed layer and $A_{14 C}$ is the ${ }^{14} \mathrm{C}$ concentration in forest litter in the analyzed layer.

The background content of ${ }^{14} \mathrm{C}$ is determined by Equation 4:

$$
{ }^{14} C_{B G(S)}=C_{S} \times 226 \times \text { Modern }
$$

where $226 \mathrm{~Bq} / \mathrm{kg} \mathrm{C}$ expresses the concentration of the "modern level" of carbon corresponding to the background level of the mass of carbon, and Modern is a relative concentration of ${ }^{14} \mathrm{C}$ that can be observed in the forest litter expressed as a percent of the Modern level.

Thus, the ${ }^{14} \mathrm{C}$ fraction caused by graphite is determined as:

$$
\Delta^{14} C={ }^{14} C_{S}-{ }^{14} C_{B G(S)}
$$

where $2.5 \times 10^{7}$ is the ${ }^{14} \mathrm{C}$ graphite concentration; 1000 is the recalculation coefficient $(\mathrm{mg} / \mathrm{kg})$; and $S_{\text {site }}$ is the collecting area $\left(\mathrm{m}^{2}\right)$ for the forest litter samples. The density of graphite deposition on each studied site has to be summed for all analyzed layers.

\section{Sampling and Sample Preparation}

The amount of deposited graphite in the environment is estimated from the results of the excess ${ }^{14} \mathrm{C}$ activity above the modern natural level (Buzinny and Talerko 1999, 2000b) in the forest litter and/ or in the soil samples. A method based on direct synthesis of lithium carbide prior to benzene (Skripkin and Kovaliukh 1998) and subsequent liquid scintillation counting (LSC) was used to measure the activity of ${ }^{14} \mathrm{C}$. The measurements were carried out using a modern low-level liquid scintillation (LS) spectrometer, Quantulus $1220^{\mathrm{TM}}$ (Wallac Oy, Finland). 


\section{Sampling Network}

More than 60 sites were included in this ${ }^{14} \mathrm{C}$ activity study. The samples covered a distance up to 60 $\mathrm{km}$ from the reactor in different directions around the Chernobyl NPP (see Figure 1). All these sites were located near settlements (Buzinny et al. 1993; Buzinny and Talerko 1999, 2000a). We collected samples of forest litter (different layers of the forest litter according to its morphological structure) and soil at 41 locations.

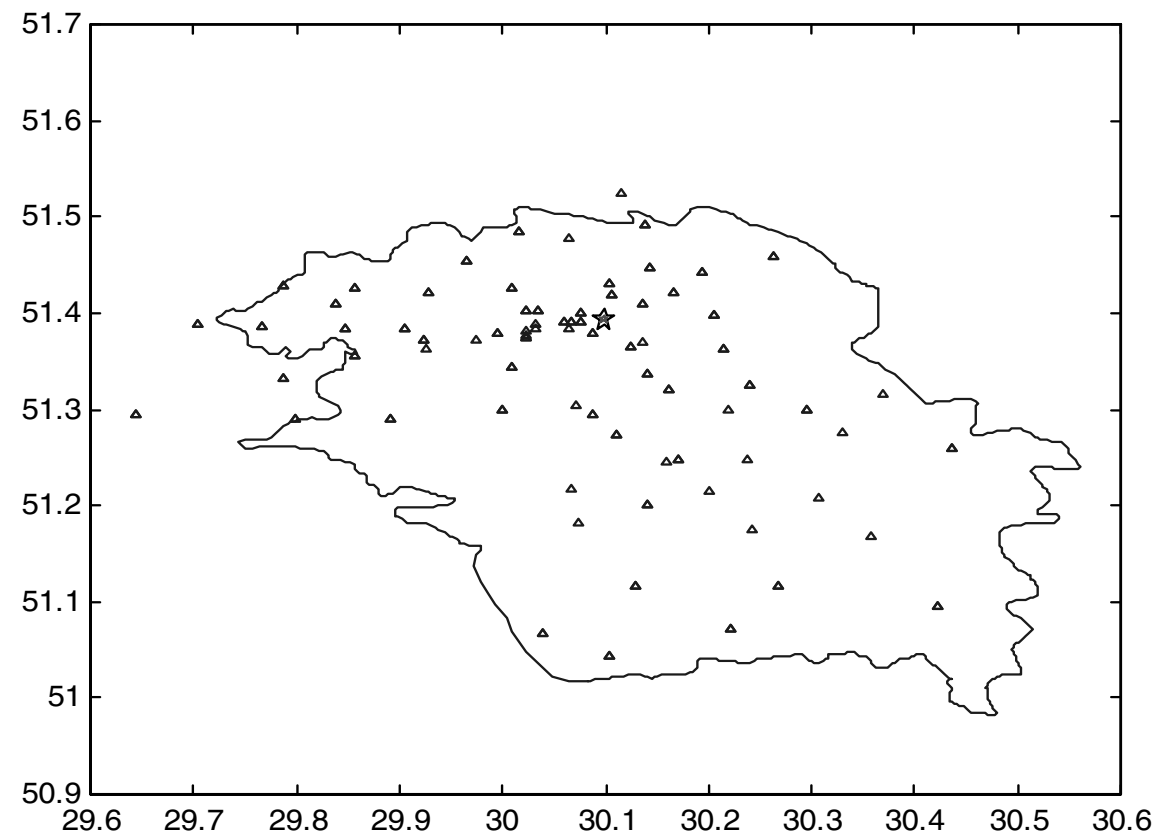

Figure 1 Sampling map for ${ }^{14} \mathrm{C}$ study (Buzinny et al. 1998; Buzinny and Talerko 1999, 2000a). The border in the map corresponds to border of the former Chernobyl district. The axes represent the latitude and longitude coordinates given in Table 2 .

The forest litter samples were collected from the surface and were sampled from an area of $2500 \mathrm{~cm}^{2}(50 \times 50 \mathrm{~cm})$. The samples were stratified by 3 layers according to their morphological state: A - upper layer: fresh sagged needles; B - middle layer: old needles without structural changes; $\mathrm{C}$ - lower layer, adjacent with upper soil layer: destroyed needles and other humus-like substances. The relative average distribution of the mass of forest litter samples for 38 sites was found to be $A=13 \pm 5 \% ; B=29 \pm 10 \%$; and $C=58 \pm 11 \%$. Samples of total litter were collected in 3 sites where we could not stratify the forest litter by layers. The soil samples were collected from 2 layers following one another at a depth of $5 \mathrm{~cm}$ each for all sites. Soil sampling was performed using the same area used for forest litter sampling $(15 \times 25 \mathrm{~cm})$. According to our research hypothesis, we assumed that graphite had been deposited into the lower layer of the forest litter (C); hence, we used the corresponding A and B layers as a background.

\section{RESULTS}

\section{Analyses of Forest Litter}

I believe that the method chosen to estimate the amount of graphite deposited on the land surface (Equations 1 and 2) is valid up to $0.2 \mathrm{mg} / \mathrm{m}^{2}$. Forest litter samples were collected at 41 sites. A total 
of 59 samples of forest litter were involved for the study and 75 analyses of ${ }^{14} \mathrm{C}$ activity were carried out, including replicates. The results obtained show that the majority of samples have a ${ }^{14} \mathrm{C}$ activity exceeding the background (Table 2) and cover a wide range.

Table 2 Dispersion of ${ }^{14} \mathrm{C}(\mathrm{pMC})$ a in the samples of various layers of forest litter for particular sites of observation. Coordinates of wood collection sites and forest litter samples for studying ${ }^{14} \mathrm{C}$ in the vicinity of the Chernobyl NPP (E longitude, N latitude) (Buzinny et al. 1998, 1999, 2000).

\begin{tabular}{|c|c|c|c|c|}
\hline Site & Longitude (E) & Latitude (N) & Layer & $\mathrm{pMC}$ \\
\hline $97 / 27$ & $29^{\circ} 58^{\prime} 30^{\prime \prime}$ & $51^{\circ} 22^{\prime} 15^{\prime \prime}$ & A & 115.0 \\
\hline $97 / 27$ & $29^{\circ} 58^{\prime} 30^{\prime \prime}$ & $51^{\circ} 22^{\prime} 15^{\prime \prime}$ & B & 127.9 \\
\hline $97 / 27$ & $29^{\circ} 58^{\prime} 30^{\prime \prime}$ & $51^{\circ} 22^{\prime} 15^{\prime \prime}$ & $\mathrm{C}$ & 108.4 \\
\hline $96 / 09$ & $30^{\circ} 10^{\prime} 0^{\prime \prime}$ & $51^{\circ} 25^{\prime} 15^{\prime \prime}$ & A & 118.8 \\
\hline $96 / 09$ & $30^{\circ} 10^{\prime} 0^{\prime \prime}$ & $51^{\circ} 25^{\prime} 15^{\prime \prime}$ & B & 125.4 \\
\hline $96 / 09$ & $30^{\circ} 10^{\prime} 0^{\prime \prime}$ & $51^{\circ} 25^{\prime} 15^{\prime \prime}$ & $\mathrm{C}$ & 235.0 \\
\hline $96 / 33$ & $30^{\circ} 3^{\prime} 38^{\prime \prime}$ & $51^{\circ} 23^{\prime} 25^{\prime \prime}$ & A & 122.5 \\
\hline $96 / 33$ & $30^{\circ} 3^{\prime} 38^{\prime \prime}$ & $51^{\circ} 23^{\prime} 25^{\prime \prime}$ & B & 126.9 \\
\hline $96 / 33$ & $30^{\circ} 3^{\prime} 38^{\prime \prime}$ & $51^{\circ} 23^{\prime} 25^{\prime \prime}$ & $\mathrm{C}$ & 132.7 \\
\hline 97/06 & $30^{\circ} 6^{\prime} 20^{\prime \prime}$ & $51^{\circ} 25^{\prime} 10^{\prime \prime}$ & A & 123.0 \\
\hline $96 / 04$ & $30^{\circ} 5^{\prime} 15^{\prime \prime}$ & $51^{\circ} 22^{\prime} 40^{\prime \prime}$ & Total & 385.3 \\
\hline $97 / 24$ & $30^{\circ} 1^{\prime} 52^{\prime \prime}$ & $51^{\circ} 23^{\prime} 3^{\prime \prime}$ & A & 126.8 \\
\hline $97 / 24$ & $30^{\circ} 1^{\prime} 52^{\prime \prime}$ & $51^{\circ} 23^{\prime} 3^{\prime \prime}$ & B & 147.8 \\
\hline $97 / 24$ & $30^{\circ} 1^{\prime} 52^{\prime \prime}$ & $51^{\circ} 23^{\prime} 3^{\prime \prime}$ & $\mathrm{C}$ & 561.2 \\
\hline $97 / 20$ & $30^{\circ} 6^{\prime} 50^{\prime \prime}$ & $51^{\circ} 31^{\prime} 30^{\prime \prime}$ & A & 116.0 \\
\hline $97 / 20$ & $30^{\circ} 6^{\prime} 50^{\prime \prime}$ & $51^{\circ} 31^{\prime} 30^{\prime \prime}$ & B & 123.4 \\
\hline $97 / 20$ & $30^{\circ} 6^{\prime} 50^{\prime \prime}$ & $51^{\circ} 31^{\prime} 30^{\prime \prime}$ & $\mathrm{C}$ & 235.2 \\
\hline 97/08 & $30^{\circ} 0^{\prime} 55^{\prime \prime}$ & $51^{\circ} 29^{\prime} 5^{\prime \prime}$ & A & 116.1 \\
\hline $97 / 08$ & $30^{\circ} 0^{\prime} 55^{\prime \prime}$ & $51^{\circ} 29^{\prime} 5^{\prime \prime}$ & B & 121.3 \\
\hline $97 / 08$ & $30^{\circ} 0^{\prime} 55^{\prime \prime}$ & $51^{\circ} 29^{\prime} 5^{\prime \prime}$ & $\mathrm{C}$ & 126.8 \\
\hline 97/06 & $30^{\circ} 6^{\prime} 20^{\prime \prime}$ & $51^{\circ} 25^{\prime} 10^{\prime \prime}$ & B & 123.8 \\
\hline $96 / 36$ & $30^{\circ} 4^{\prime} 30^{\prime \prime}$ & $51^{\circ} 24^{\prime} 0^{\prime \prime}$ & Total & 188.1 \\
\hline $96 / 28$ & $29^{\circ} 54^{\prime} 18^{\prime \prime}$ & $51^{\circ} 23^{\prime} 3^{\prime \prime}$ & A & 108.3 \\
\hline $96 / 28$ & $29^{\circ} 54^{\prime} 18^{\prime \prime}$ & $51^{\circ} 23^{\prime} 3^{\prime \prime}$ & B & 132.9 \\
\hline $96 / 28$ & $29^{\circ} 54^{\prime} 18^{\prime \prime}$ & $51^{\circ} 23^{\prime} 3^{\prime \prime}$ & $\mathrm{C}$ & 442.5 \\
\hline $96 / 02$ & $30^{\circ} 1^{\prime} 20^{\prime \prime}$ & $51^{\circ} 22^{\prime} 25^{\prime \prime}$ & A & 113.7 \\
\hline $96 / 02$ & $30^{\circ} 1^{\prime} 20^{\prime \prime}$ & $51^{\circ} 22^{\prime} 25^{\prime \prime}$ & B & 141.0 \\
\hline $96 / 02$ & $30^{\circ} 1^{\prime} 20^{\prime \prime}$ & $51^{\circ} 22^{\prime} 25^{\prime \prime}$ & $\mathrm{C}$ & 180.0 \\
\hline $\mathrm{TL}^{\mathrm{b}}$ & - & - & A & 130.0 \\
\hline $\mathrm{TL}^{\mathrm{b}}$ & - & - & B & 272.0 \\
\hline $\mathrm{TL}^{\mathrm{b}}$ & - & - & $\mathrm{C}$ & 378.0 \\
\hline 97/06 & $30^{\circ} 6^{\prime} 20^{\prime \prime}$ & $51^{\circ} 25^{\prime} 10^{\prime \prime}$ & $\mathrm{C}$ & 149.1 \\
\hline $96 / 34$ & $30^{\circ} 4^{\prime} 30^{\prime \prime}$ & $51^{\circ} 23^{\prime} 26^{\prime \prime}$ & Total & 135.5 \\
\hline
\end{tabular}

${ }^{a}$ pMC is the percent of "modern" ${ }^{14} \mathrm{C}$, a relative unit that expresses the ${ }^{14} \mathrm{C}$ activity in the carbon of the oak wood of 1890 growth $(100 \mathrm{pMC}=226 \mathrm{~Bq} / \mathrm{kg} \mathrm{C})$.

${ }^{\mathrm{b}}$ The sampling site is outside our network.

\section{Forest Litter}

Reproducibility of the ${ }^{14} \mathrm{C}$ activity determinations of the samples of forest litter was determined for the 5 most contrasting samples ( 5 replicates for each). We found that the relative standard deviation ranged from 5.1 to $13.7 \%$ (Table 3 ). There are discrepancies in the results for the same collecting 
sites and corresponding layers in Tables 2 and 3, because the results of single measurements are presented in Table 2 and average results for the same samples are demonstrated in Table 3.

Table 3 Relative content of ${ }^{14} \mathrm{C}$ (pMC) in forest litter samples for 5 of the most contrasting observation sites (the average results of 5 replicates for each sample).

\begin{tabular}{lllcl}
\hline Site & Layer & ${ }^{14} \mathrm{C}$ & Standard deviation & Relative deviation $(\%)$ \\
\hline $97 / 27$ & $\mathrm{C}$ & 938.9 & 128.7 & 13.7 \\
$96 / 28$ & $\mathrm{C}$ & 417 & 43.1 & 10.4 \\
$\mathrm{TL}$ & $\mathrm{C}$ & 414.0 & 42.9 & 10.4 \\
$96 / 04$ & Total & 326.3 & 43.1 & 13.2 \\
$96 / 02$ & $\mathrm{C}$ & 181 & 9.1 & 5.1 \\
\hline
\end{tabular}

A particularly high difference is observed for site TL (Table 3), where ${ }^{14} \mathrm{C}$ levels for $\mathrm{A}, \mathrm{B}$, and C layers are 135, 275, and $380 \mathrm{pMC}$, respectively. The A and B layers of forest litter apparently have significant ${ }^{14} \mathrm{C}$ contamination. A similar increase in the ${ }^{14} \mathrm{C}$ level of layer B was found at site 97/24. Meanwhile, a series of observation sites located near the Chernobyl NPP have either very low levels of ${ }^{14} \mathrm{C}$ or values close to the detection limit. It was assumed that decontamination work might have been done at those sites. In this case, the layer of litter containing the deposited graphite had been collected and removed to the burial ground. It is possible that the graphite was moved to the upper layer of the soil. Tests of the soils ( $0-5$-cm layer) and new collections of forest litter samples for secondary tests will help in future comparisons.

\section{Soil Study}

Soil samples corresponding to the forest-litter collection sites that contained the maximum determined levels of the deposited graphite were analyzed to determine the amount of ${ }^{14} \mathrm{C}$. All soil samples were initially dried at $150{ }^{\circ} \mathrm{C}$. The amount of organic matter for each soil sample was estimated by burning $1 \mathrm{~g}$ of sample material. The samples $(200 \mathrm{~g})$ were then mixed with an adequate amount of pyrolusite $\left(\mathrm{MgO}_{2}\right)$ at the upper part of the reactor of carbide lithium synthesis. The calculations of graphite balance for soil were done in a similar way as the calculations of graphite balance for forest litter. These results are shown in Table 5.

Comparing the values obtained of the graphite deposition density (Tables 4 and 5) for samples 97/ $27,96 / 13$, and 96/04, we received a corresponding series of values for the graphite fraction of the soil: $4.9 \%, 19.4 \%$, and $1.5 \%$. We expect the most likely explanation for this interval is the consistency of samples from the different strata during sample collection.

Table 4 shows the ${ }^{14} \mathrm{C}$ and graphite balance in the forest litter for different observation sites. The results include the sites where the graphite content does not exceed $0.1-0.2 \mathrm{mg} / \mathrm{m}^{2}$ (the detection level). Excessive levels of ${ }^{14} \mathrm{C}$ cannot be determined for a number of sites due to the discrepancy in the ${ }^{14} \mathrm{C}$ level for different layers. The maximum value $\left(52.6 \mathrm{mg} / \mathrm{m}^{2}\right)$ of graphite is determined for a site $9 \mathrm{~km}$ west of the Chernobyl NPP.

\section{CONCLUSIONS}

This paper demonstrates an application of ${ }^{14} \mathrm{C}$ study for practical reconstruction of accidental releases from a nuclear power plant that used a graphite reactor. The sensitivity of the method is adequate for conducting analyses of samples collected at distances up to $10 \mathrm{~km}$. Both components of accidental releases of ${ }^{14} \mathrm{C}$ of the Chernobyl NPP can be used for research on ${ }^{14} \mathrm{C}$ distribution. 
Table 4 Balance of ${ }^{14} \mathrm{C}$ and graphite in the forest litter for different sites of observation. ${ }^{\mathrm{a}}$

\begin{tabular}{lrllrrlrl}
\hline $\begin{array}{l}\text { Site } \\
\text { code }\end{array}$ & $\begin{array}{l}\text { Distance } \\
(\mathrm{km})\end{array}$ & $\begin{array}{l}\text { Nr of } \\
\text { layers }\end{array}$ & $\begin{array}{l}\text { Sample } \\
\text { mass }(\mathrm{g})\end{array}$ & $\begin{array}{l}\text { Carbon } \\
\text { mass }(\mathrm{g})\end{array}$ & $\begin{array}{l}{ }^{14} \mathrm{C} \\
(\mathrm{Bq})\end{array}$ & $\begin{array}{l}\text { Background } \\
{ }^{14} \mathrm{C}(\mathrm{Bq})\end{array}$ & $\begin{array}{r}\mathrm{A}^{14} \mathrm{C} \\
(\mathrm{Bq})\end{array}$ & $\begin{array}{l}\sigma \\
\left(\mathrm{mg} / \mathrm{m}^{2}\right)\end{array}$ \\
\hline $97 / 27$ & 8.98 & 3 & 900 & 149.4 & 368.1 & 39.3 & 328.8 & 52.6 \\
$96 / 04$ & 1.89 & 1 & 215 & 32.4 & 28.4 & 8.5 & 19.8 & 21.1 \\
$97 / 24$ & 4.85 & 3 & 926 & 223.4 & 174.5 & 58.8 & 115.6 & 18.5 \\
$96 / 28$ & 13.52 & 3 & 440 & 81.1 & 87.2 & 21.4 & 65.8 & 10.5 \\
$97 / 20$ & 14.67 & 3 & 1005 & 200.5 & 107.1 & 52.8 & 54.3 & 8.6 \\
$96 / 36$ & 1.87 & 3 & 1440 & 364.6 & 120.9 & 96.0 & 24.9 & 3.9 \\
$96 / 02$ & 5.78 & 3 & 828 & 176.9 & 60.3 & 46.6 & 13.8 & 2.2 \\
$96 / 13$ & 2.31 & 3 & 697 & 150.0 & 49.8 & 39.5 & 10.3 & 1.6 \\
$96 / 38$ & 6.89 & 1 & 570 & 126.0 & 39.9 & 33.2 & 6.7 & 1.0 \\
$97 / 26$ & 12.47 & 1 & 450 & 94.6 & 29.7 & 24.9 & 4.8 & 0.77 \\
$96 / 17$ & 3.63 & 3 & 585 & 126.8 & 38.0 & 33.4 & 4.7 & 0.74 \\
$97 / 23$ & 3.68 & 1 & 270 & 60.5 & 20.0 & 15.9 & 4.1 & 0.65 \\
$96 / 09$ & 5.56 & 3 & 570 & 68.0 & 21.9 & 17.9 & 4.0 & 0.64 \\
$97 / 22$ & 13.35 & 1 & 1300 & 130.7 & 38.2 & 34.4 & 3.8 & 0.60 \\
$96 / 23$ & 22.67 & 1 & 480 & 57.8 & 18.6 & 15.2 & 3.4 & 0.54 \\
$96 / 33$ & 2.73 & 3 & 485 & 93.3 & 27.3 & 24.6 & 2.7 & 0.43 \\
$97 / 06$ & 2.95 & 3 & 709 & 72.4 & 21.5 & 19.1 & 2.4 & 0.39 \\
$96 / 34$ & 1.73 & 1 & 42 & 7.6 & 2.3 & 2.0 & 0.3 & 0.36 \\
$97 / 08$ & 11.73 & 3 & 600 & 110.3 & 30.7 & 29.1 & 1.6 & 0.26 \\
$96 / 24$ & 17.45 & 1 & 380 & 57.4 & 16.3 & 15.1 & 1.1 & 0.18 \\
$96 / 10$ & 7.24 & 1 & 330 & 42.1 & 12.1 & 11.1 & 1.0 & 0.16 \\
$96 / 18$ & 9.15 & 1 & 445 & 95.1 & 26.0 & 25.0 & 1.0 & 0.16 \\
$97 / 21$ & 9.62 & 1 & 345 & 74.7 & 20.6 & 19.7 & 0.9 & 0.15 \\
$96 / 25$ & 17.27 & 1 & 600 & 105.7 & 28.6 & 27.8 & 0.8 & 0.12 \\
\hline
\end{tabular}

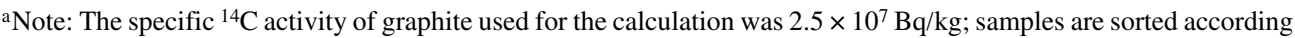
to the level of deposited graphite on the land surface.

Table 5 Balance of ${ }^{14} \mathrm{C}$ and graphite $\left(\mathrm{C}, \mathrm{mg} / \mathrm{m}^{2}\right)$ in soil samples $(0-5)$ for different sites.

\begin{tabular}{llllll}
\hline Site & $\begin{array}{l}\text { Mass } \\
(\mathrm{g})\end{array}$ & $\begin{array}{l}{ }^{14} \mathrm{C} \\
(\mathrm{pMC})\end{array}$ & $\begin{array}{l}\mathrm{C}_{6} \mathrm{H}_{6} \\
(\mathrm{~g})\end{array}$ & $\begin{array}{l}\text { Excess }{ }^{14} \mathrm{C} \\
(\mathrm{Bq}))^{\mathrm{a}}\end{array}$ & $\begin{array}{l}\text { Graphite } \\
\left(\mathrm{mg} / \mathrm{m}^{2}\right)\end{array}$ \\
\hline $97 / 27$ & 1525 & 367.8 & 0.637 & 2.55 & 2.72 \\
$96 / 13$ & 1420 & 147.5 & 1.129 & 0.53 & 0.56 \\
$96 / 04$ & 1925 & 141.8 & 0.569 & 0.30 & 0.32 \\
$96 / 13$ & 1420 & 132.5 & 0.885 & 0.22 & 0.23 \\
$97 / 14$ & 2065 & 128.7 & 0.561 & 0.15 & 0.16 \\
$96 / 02$ & 1625 & 137.0 & 0.473 & 0.17 & 0.18 \\
$96 / 13$ & 1420 & 128.7 & 0.669 & 0.13 & 0.13 \\
$97 / 14$ & 2065 & 123.2 & 0.561 & 0.09 & 0.09 \\
$96 / 02$ & 1625 & 132.8 & 0.473 & 0.13 & 0.14 \\
$96 / 24$ & 1710 & 121.9 & 0.441 & 0.05 & 0.05 \\
\hline
\end{tabular}

${ }^{\text {a Excess }}{ }^{14} \mathrm{C}$ in Bq per soil sample collected (sampling area $15 \mathrm{~cm} \times 25 \mathrm{~cm} \times 5 \mathrm{~cm}$ ).

We should consider that various natural and human activity factors can affect the behavior and transport of the graphite in the environment. As a result of this ${ }^{14} \mathrm{C}$ study that includes the analyses of different layers of forest litter and soil in the vicinity of the Chernobyl NPP, we can estimate the amount of graphite deposited on the land surface and we have the information required to forecast 
the implications of this deposition. A comparison of graphite dispersion in forest litter and soil revealed that the fraction of graphite deposited in the soil reached $20 \%$ for the sampling conducted in 1997.

The release of graphite due to the accident at the Chernobyl NPP has caused the formation of the contaminant traces in the environment reaching a density of $52.6 \mathrm{mg} / \mathrm{m}^{2}$ observed in a site $9 \mathrm{~km}$ west of the Chernobyl NPP.

\section{ACKNOWLEDGMENTS}

The author gratefully acknowledges the staff of the Ecocenter Enterprise for the assistance in sampling of wood and forest litter. Thanks are extended to the research workers at the laboratories for Radioecology and Radiochemistry of the RCRM of the AMS of Ukraine for their support of this study. I am also grateful to Dmitriy Vysotskyy for translation of the paper. My special thanks to Ljubov Savon for her careful reading and partial rewriting of the paper.

\section{REFERENCES}

Begichev SN, Borovoi AA, Burlakov EB. 1990. Nuclear fuel of 4th reactor of Chernobyl NPP [report]. Moscow: Institute of Nuclear Energy. 5268/3, 21 p. In Russian.

Buzinny MG, Talerko NN. 1999. Current state of radiocarbon studies concerning to retrospective reconstruction of accidental releases of Chernobyl NPP. Methods of Liquid Scintillation Counting in Radioecology 3:13-25. In Russian.

Buzinny MG, Talerko NN. 2000a. Retrospective investigation of radiocarbon of Chernobyl accidental releases origin. Hygiene of Settlements 36(1):246-60. In Russian.

Buzinny MG, Talerko NN. 2000b. Operational releases of Chernobyl NPP. Hygiene of Settlements 36(1):234-42. In Ukrainian.

Buzinny MG, Zelensky AV, Kovaliukh NN, Skripkin VV, Sanin EV. 1993. Retrospective reconstruction of accidental ${ }^{14} \mathrm{C}$ release to atmosphere due to Chernobyl accident. Kiev: Ukrainian Research Center for Radiation Medicine HM SM of Ukraine. p 118-24. In Russian.

Buzinny M, Kovaliukh N, Likhtarev I, Los' I, Nesvetajlo V, Pazdur MF, Sobotovich E, Skripkin V. 1995. Ecological chronology of nuclear fuel cycle sites. Radiocarbon 37(2):469-73.

Buzinny M, Likhtarjov I, Los' I, Talerko N, Tsigankov N. 1998. Radiocarbon analysis of annual tree rings from the vicinity of the Chernobyl NPP. Radiocarbon 40(1):37380.
Buzulukov YP, Dobrynin YL. 1993. Release of radionuclides during the Chernobyl accident. In: Merwin SE, Balonov MI, editors. The Chernobyl Papers. Volume 1. Doses to the Soviet Population and Early Health Effects Studies. Richland, Washington, USA: Research Enterprises Publishing Segment. p 3-21.

Borovoi AA. 1995. Estimation of conditions of nuclear, radiation and ecological safety of the "Shelter" [scientific report]. Moscow: Kurchatov Institute. In Russian.

Gaiko VB, Korablev N, Solovjev EN, Trosheva TI, Shamov VP, Umanets MP, Shcherbina VG. 1985. Discharge of ${ }^{14} \mathrm{C}$ of nuclear power plants with RBMK-1000 reactor. Atomnaja Energiya 59:144-5. In Russian.

Kovaliukh NN, Skripkin VV. 1998. ${ }^{14} \mathrm{C}$ cycle in the hot zone around Chernobyl. Radiocarbon 40(1):391-7.

Kovaliukh NN, Skripkin VV, Sobotovich EV, Buzinny MG, Sanin EV. 1994. Radiocarbon of Chernobyl accidental release in tree rings in the vicinity of Chernobyl NPP. Zeszyty naukowe Politechniki Slaskiej. Seria: Matematyka-Fizyka z.71 Nr. kol.1229. p 214-24. In Russian.

Salonen L. 1987. Carbon-14 and tritium in air in Finland after the Chernobyl accident. Radiochimica Acta 41:1458.

Skripkin V, Kovaliukh N. 1998. Recent developments in the procedures used at the SSCER laboratory for the routine preparation of lithium carbide. Radiocarbon 40(1):2114. 